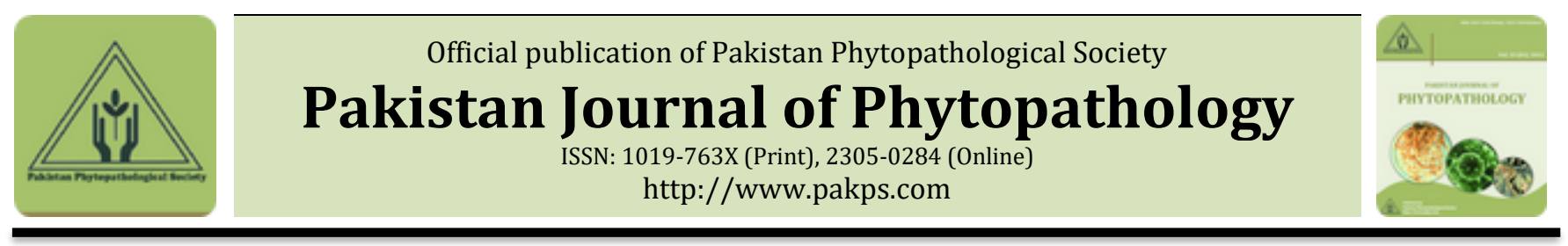

\title{
PRI MUNG-2018 : A NEW MUNGBEAN VARIETY RELEASED IN PAKISTAN FOUND RESISTANT TO VIRAL DISEASES
}

\author{
${ }^{a}$ Muhammad S. Saeed, aSadia Kaukab, aChaudhary M. Rafiq, bAziz U.Rehman, aAqsa Tahir, aGhulfam Riasat, \\ aEhsan Khan, cSobia Ijaz \\ aPulses Research Institute, Ayub Agriculture Research Institute (AARI), Faisalabad, Pakistan. \\ ${ }^{b}$ Wheat Research Institute, Ayub Agriculture Research Institute (AARI), Faisalabad, Pakistan. \\ ${ }^{c}$ Agronomic research institute, Ayub Agriculture Research Institute (AARI), Faisalabad, Pakistan.
}

\begin{abstract}
A B S T R A C T
A cross was made between Line No.1 and E-321 in 2002. The material was handled in filial generations following pedigree method from 2002-2018. It was tested in yield trials 2009-14 and was found high yielding as compared to check variety AZRI Mung-2006. In disease screening nurseries it had shown good disease resistance against Mung bean yellow mosaic virus, Urdbean Leaf Crinkle virus and Cercospora disease. It also exhibited tolerance to insect pests. In addition to this, proposed variety needs no special production technology package and fit in a better way in Rice-Wheat cropping system or between wheat and succeeding crop as catch crop due to short duration. The new variety PRI Mung-2018 is suitable for all areas of Punjab province.
\end{abstract}

Keywords: new variety, mung bean, PRI Mung-2018, Pakistan, yield.

\section{INTRODUCTION}

Mungbean (Vigna radiata (L.) R. Wilczek) is a legume cultivated for its edible seeds and sprouts across Asia. It is a major edible legume seed in Asia (India, South East-Asia and East Asia) and is also eaten in Southern Europe and in the Southern USA. Legumes like beans, peas, lentils and groundnut belongs to the family leguminosae/fabaceae and play important role in human nutrition because these are rich source of protein, calories, certain minerals and vitamins (Deshpande et al, 1992). Many recent studies have been conducted on the nutritional quality of $V$. radiata and V. Mungo (Blessing et al, 2010) and (Hussain et al, 2010). These studies suggested that these beans are good source of protein, carbohydrate and minerals (Suneja et al. 2011). Mung beans are cooked fresh or dry. They can be eaten whole or made into flour, soups, porridge, snacks, bread, noodles and ice-cream. Split seeds can be transformed into

Submitted: July 13, 2018

Revised: August 02, 2018

Accepted for Publication: October 24, 2018

* Corresponding Author:

Email: aqsatahir24@yahoo.com

(C) 2017 Pak. J. Phytopathol. All rights reserved. dhaal in the same way as black gram or lentils. Mung beans can be processed to make starch noodles (vermicelli, bean thread noodles, cellophane noodles) or soap.

Mung bean is the major kharif pulse crop grown in Punjab on an area of 116.78 thousand hectare with a production of 78.46 thousand tons (Anonymous 2016-17). In Pakistan, the area under Mung bean cultivation over the last five years has been recorded to be between 130 to 140 thousand hectares with a production of 90 to 98 thousand tons. On National level, Punjab leads the Mung bean production with $87 \%$ share, Balochistan 6\%, KPK 5\% and Sindh $4 \%$. Seed yield of Mung bean per acre is very low which is due to low varietal potential along with poor management practices.

Research activities on mungbean breeding carried out in this project resulted in the significant achievement regarding release of the variety SML 668 which is the first early-maturing and high-yielding variety found most suitable for cultivation in the present rice-wheat system of Indo-Gangetic plains (Brar et al. 2004).

Any disturbance in the metabolic processes caused by various biotic and abiotic stresses faced by the plant may reduce the actual yield. The severity of various stresses is 
largely due to varying weather conditions that prevail year after year, thus lowering pulses yield at farmer's field and potential yield. The susceptibility to diseases is the major constraint causing low seed yield. Among the viral diseases, Mung bean yellow mosaic virus is very devastating in Pakistan especially in summer season. The disease is characterized by the appearance of yellow specks or spots on young leaves and the emerging trifoliate leaves manifest irregular yellow and green patches causing reduction in leaf size. In severe cases there is complete yellowing of leaves followed by stunted growth, few flowers and pods with shriveled seeds. Disease incidence ranges between 30$100 \%$ causing yield losses that range between $60-80 \%$, depending upon the disease severity and the crop stage at which plants get infected. However, in naturally infected susceptible cultivars it varies with the time of infection and yield losses may reach up to $100 \%$ (complete crop failure).

\section{MATERIALS AND METHODS}

A cross between two parents Line No. 1 and E-321 was made at Pulses Research Institute, AARI, Faisalabad in kharif 2001. By following pedigree method material was handled in filial generations. This strain was tested in a series of trial on research stations and throughout the Mung bean growing areas of Punjab and it out yielded check variety AZRI-2006. In national uniform yield trial it surpassed the check variety NM-2011 and stood eighth position during kharif 2013, whereas in kharif 2014 it stood second position in NUYT. Its maximum yield potential of $2119 \mathrm{~kg} / \mathrm{ha}$ was achieved in NIAB in national uniform yield trial kharif 2014. The new strain possesses in-built moderate resistance against Mung bean yellow mosaic virus, Urdbean Leaf Crinkle virus and Cercospora disease. It also exhibited tolerance to insect pests. In addition to this, proposed variety needs no special Detail of Hybridization and Selection

\begin{tabular}{lll}
\hline Year & Filial generation/trial & Operation \\
\hline 2002 & Cross was attempted & Fo seed was harvested \\
2003 & $\mathrm{~F}_{1}$ & Seed of F1 cross harvested \\
2004 & $\mathrm{~F}_{2}$ & Single plant selection \\
2005 & $\mathrm{~F}_{3}$ & Single plant selection \\
2006 & $\mathrm{~F}_{4}$ & Single plant selection \\
2007 & $\mathrm{~F}_{5}$ & Single plant selection \\
2008 & $\mathrm{~F}_{6}$ & Superior Progeny line selected \\
2009 & Preliminary Yield Trial & Yield Data \\
2010 & Advanced Yield Trial & - \\
2011 & Advanced Yield Trial & - \\
2012 & Micro Yield Trial & - \\
2013 & National Uniform Yield Trial & - \\
2014 & National Uniform Yield Trial & - \\
\hline
\end{tabular}

production technology package and fit in a better way in Rice-Wheat cropping system or between wheat and succeeding crop as catch crop due to short duration. The new strain is suitable for all areas of Punjab province.

\section{RESULTS}

Agronomic Studies: Planting date studies and fertilizer trials were conducted at Pulses Research Institute, Faisalabad during 2015-2016 to fix specific agronomic requirements of the candidate variety V-08009. It was observed that the new strain adheres to the existing production technology and needed no special treatments.

The detail is as under:

\section{Diseases and Insect Pests Reaction}

Insect Pests: Insect Pest's infestation studies for whitefly, Jassid, Espanola bug and Pod borer were carried out during 2015-2016 at Pulses Research Institute, AARI, Faisalabad

Mungbean Yellow Mosaic Virus: The screening studies were carried out at Pulses Research Institute AARI, Faisalabad during 2015-2016. The candidate line V-08009 resistant (R) group.

Urdbean Leaf Crinkle Virus and Cercospora Leaf Spot Disease: The screening against ULCV and Cercospora was conducted at Pulses Research Institute AARI, Faisalabad during 2015-2016. . The candidate line V-08009 and check variety AZRI-06 was placed in moderate resistant (R) group.

The new strain V-08009 is also very much responsive to Rhizobial Inoculation. Number of nodules and yield increased significantly by inoculation of Rhizobial as compared to check AZRI-06.

Quality Characteristics: This new candidate line is suitable for table purpose both as whole as well as split (Dhaal). and check variety AZRI-06 was placed in moderate 
Detail of Parental Material

\begin{tabular}{|c|c|c|c|c|}
\hline \multicolumn{5}{|c|}{ Characteristics } \\
\hline $\begin{array}{l}\text { Line No.1 } \\
\text { E-321 }\end{array}$ & \multicolumn{3}{|c|}{$\begin{array}{l}\text { Bold Seeded, Resistant to MYMD, High yielding } \\
\text { Short duration, Short stature }\end{array}$} & \\
\hline \multicolumn{5}{|c|}{ Parentage/Pedigree: Line No. 1 X E-321 MC1008-05-11-08-06-03-09 } \\
\hline Species & \multicolumn{4}{|c|}{ Vigna radiata $\mathrm{L}}$. \\
\hline Planting Date & \multicolumn{4}{|c|}{2015 (Yield kg/ha) } \\
\hline \multicolumn{2}{|l|}{ Sowing Date } & V-08009 & NM-11 & AZRI-06 \\
\hline \multirow{2}{*}{\multicolumn{2}{|c|}{$\begin{array}{l}15 \text { March } \\
1^{\text {st }} \text { April }\end{array}$}} & 1018 & 1025 & 915 \\
\hline & & 1130 & 1149 & 1042 \\
\hline 15 April & & 1210 & 1135 & 978 \\
\hline \multicolumn{2}{|l|}{$1^{\text {st }}$ May } & 1280 & 1025 & 894 \\
\hline \multicolumn{2}{|l|}{15 May } & 1235 & 933 & 864 \\
\hline \multicolumn{2}{|l|}{ Average } & 1175 & 1053 & 939 \\
\hline \multicolumn{5}{|c|}{ Planting Date 2016 (Yield kg/ha) } \\
\hline \multicolumn{2}{|c|}{ Sowing date } & V-08009 & AZRI-06 & NM-11 \\
\hline \multicolumn{2}{|l|}{15 March } & 988 & 928 & 1164 \\
\hline \multicolumn{2}{|l|}{$1^{\text {st }}$ April } & 1067 & 1026 & 1095 \\
\hline \multicolumn{2}{|l|}{15 April } & 1124 & 960 & 1014 \\
\hline \multicolumn{2}{|l|}{$1^{\text {st }}$ May } & 1320 & 928 & 996 \\
\hline \multicolumn{2}{|l|}{15 May } & 1310 & 906 & 970 \\
\hline \multicolumn{2}{|l|}{ Average } & 1162 & 950 & 1048 \\
\hline \multicolumn{5}{|c|}{ Fertilizer Trial 2016} \\
\hline \multicolumn{2}{|c|}{ Fertilizer level N-P-K(kg/ha) } & V-08009 & AZRI-06 Yield (kg/ha) & NM-11 Yield (kg/ha) \\
\hline \multicolumn{2}{|l|}{$\mathrm{T}_{1} 0-0-0$} & 994 & 854 & 992 \\
\hline \multicolumn{2}{|l|}{$\mathrm{T}_{2} 12-30-0$} & 1088 & 926 & 1006 \\
\hline \multicolumn{2}{|l|}{$\mathrm{T}_{3} 24-60-0$} & 1236 & 1178 & 1278 \\
\hline \multicolumn{2}{|l|}{$\mathrm{T}_{4} 36-90-0$} & 1240 & 1250 & 1217 \\
\hline \multicolumn{2}{|l|}{ Average } & 1140 & 1052 & 1124 \\
\hline
\end{tabular}

Insect Pests: Insect Pest's infestation studies for whitefly, Jassid, Espanola bug and Pod borer were carried out during 2015-2016 at Pulses Research Institute, AARI, Faisalabad. The data collected is as under:

\begin{tabular}{ccccccc}
\hline $\begin{array}{c}\text { Sr. } \\
\text { No. }\end{array}$ & $\begin{array}{c}\text { Line/ } \\
\text { Variety }\end{array}$ & $\begin{array}{c}\text { Whitefly Avg. } \\
\text { pop./ leaf }\end{array}$ & $\begin{array}{c}\text { Jassid Avg. } \\
\text { pop./ leaf }\end{array}$ & $\begin{array}{c}\text { Pod Borer Avg. } \\
\text { infes. \% age }\end{array}$ & $\begin{array}{c}\text { Espanola Bug Avg. } \\
\text { Pop./ plant }\end{array}$ & $\begin{array}{c}\text { Avg. grain } \\
\text { yield kg/ha }\end{array}$ \\
\hline 1 & V-08009 & 2.40 & 1.20 & 2.60 & 4.80 & 865 \\
2 & AZRI-06 & 2.00 & 0.80 & 2.20 & 4.20 & 850 \\
\hline
\end{tabular}

\begin{tabular}{|c|c|c|c|c|c|}
\hline Sr. No. & Variety & Mung bean yellow mosaic virus & Urdbean 1 & e virus & Cercospora disease \\
\hline 1 & PRI Mung-2018 & Moderately resistant & Moderate & & Moderately resistant \\
\hline \multicolumn{6}{|c|}{ Bacteriological Studies } \\
\hline \multirow{3}{*}{\multicolumn{2}{|c|}{ Rhizobial Inoculation }} & \multicolumn{4}{|c|}{ No. of Nodules } \\
\hline & & \multicolumn{2}{|c|}{2015} & \multicolumn{2}{|r|}{2016} \\
\hline & & V-08009 & AZRI-06 & V-08009 & AZRI-06 \\
\hline Un-ino & lation & 15 & 16 & 14 & 14 \\
\hline \multirow{2}{*}{\multicolumn{2}{|c|}{ Inoculation }} & 24 & 22 & 26 & 23 \\
\hline & & \multicolumn{4}{|c|}{ Yield kg/ha } \\
\hline \multicolumn{2}{|c|}{ Uninoculation } & 987 & 870 & 1011 & 843 \\
\hline \multirow{2}{*}{\multicolumn{2}{|c|}{ Inoculation }} & 1134 & 954 & 1195 & 958 \\
\hline & & 14.89 & 9.65 & 18.19 & 13.6 \\
\hline
\end{tabular}




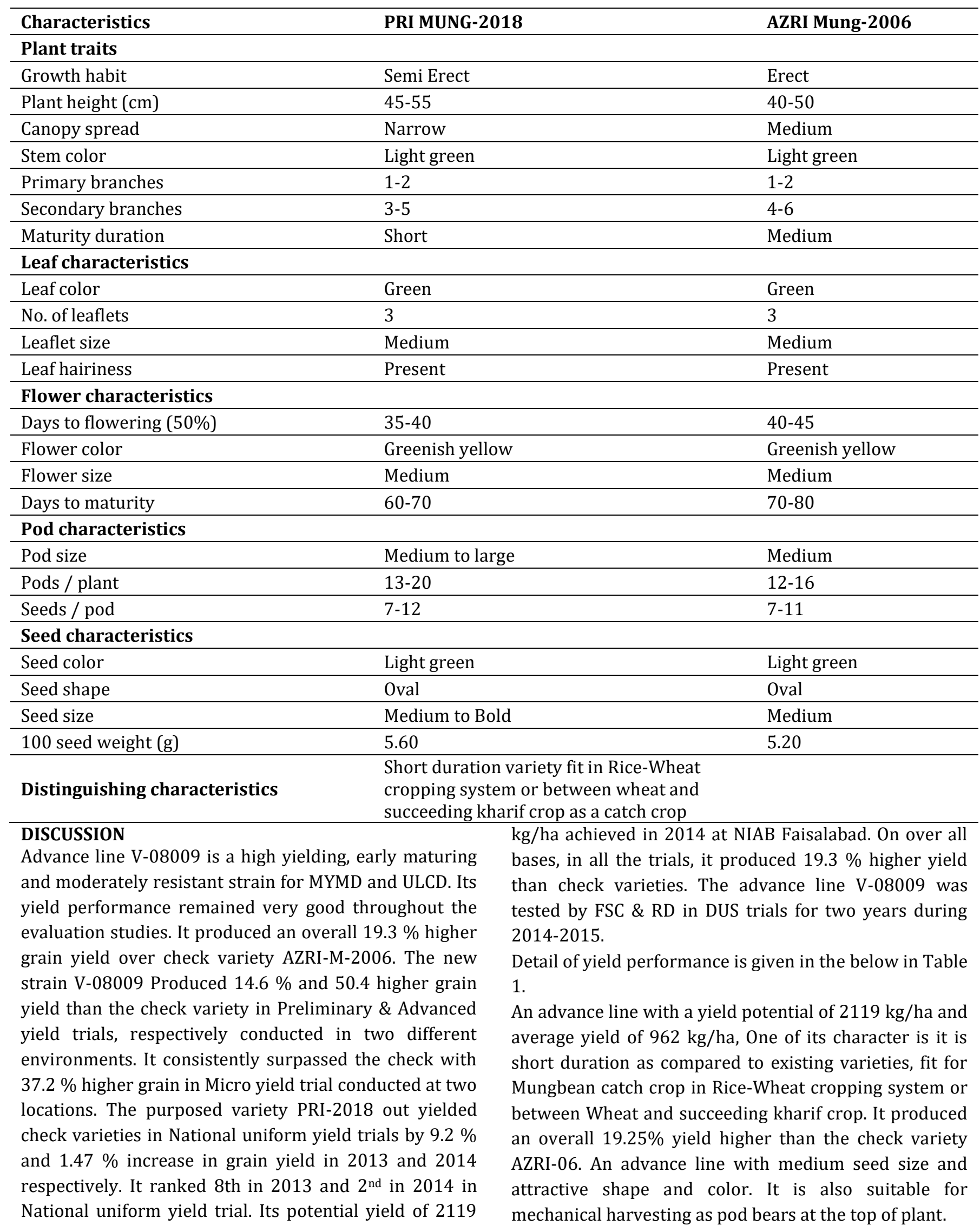


Table 1. Yield performance of Advance Line V-08009 in different yield trials

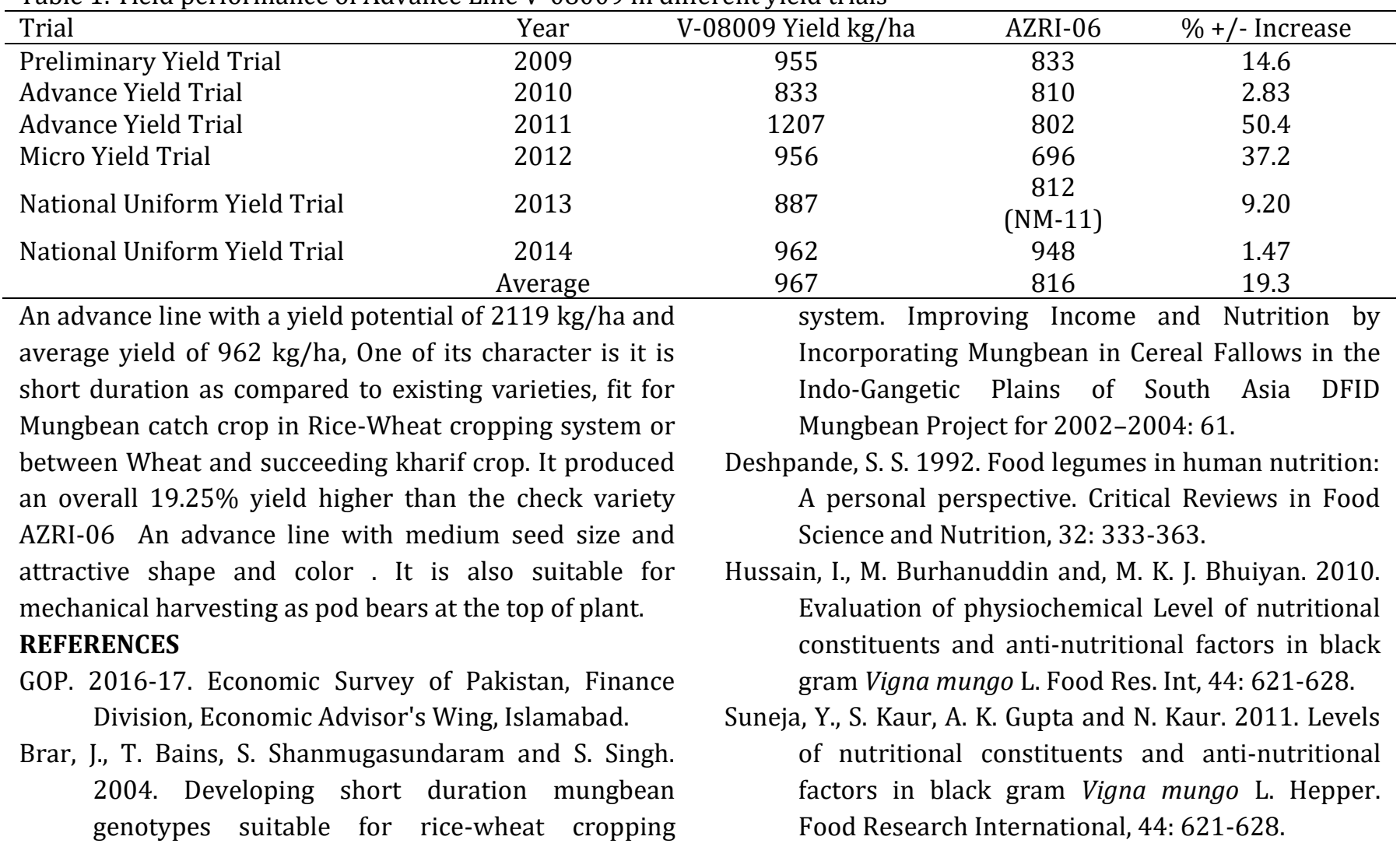

